\title{
EFFECTIVENESS OF AN INTERDISCIPLINARY PROGRAM IN PATIENTS WITH FAILED BACK SURGERY SYNDROME
}

\author{
EFICÁCIA DE UM PROGRAMA INTERDISCIPLINAR EM PACIENTES COM SÍNDROME \\ POS-LAMINECTOMIA
}

\section{EFICACIA DE UN PROGRAMA INTERDISCIPLINARIO EN PACIENTES CON SÍNDROME POSTLAMINECTOMÍA} \author{
Randolfo dos Santos Junior², Gerardo Maria de Araujo Filho ${ }^{4}$, Marielza Regina Ismael Martins 3 \\ 1. Faculdade de Medicina de São José do Rio Preto, Departamento de Ortopedia e Traumatologia, São José do Rio Preto, SP, Brazil. \\ 2. Faculdade de Medicina de Rio Preto, Hospital de Base de São José do Rio Preto, São José do Rio Preto, SP, Brazil. \\ 3. Faculdade de Medicina de São José do Rio Preto, Departamento de Ciências Neurológicas, São José do Rio Preto, SP, Brazil. \\ 4. Faculdade de Medicina de São José do Rio Preto, Departamento de Psiquiatria e Psicologia Médica, São José do Rio Preto, SP, Brazil.
}

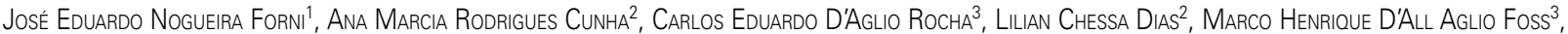

\begin{abstract}
Objective: To evaluate the results of an interdisciplinary program administered to patients with failed back surgery syndrome, aiming at functional improvement, modulation of pain, reduction of anxiety symptoms and depression, and improvement of quality of life. Method: This is a non-randomized prospective study with a sample of patients with failed back surgery pain syndrome diagnosed with persistent or recurrent pain after surgery to the lumbar spine (laminectomy and arthrodesis) referred to liaison in the Pain Clinic $(n=26)$. The instruments used were Brief Pain Inventory, Roland-Morris Questionnaire and Beck Anxiety and Depression Inventories. The generic WHOQOL-bref ${ }^{13}$ questionnaire was used to evaluate the quality of life and the fear of moving was assessed by the Tampa Scale for Kinesiophobia. Results: There was a predominance of females, the mean age was $42.3 \pm 5.8$ years, $43 \%$ were married and average schooling was $7 \pm 4.5$ years. The mean time of pain reported was $8 \pm 6.8$ months in addition to high levels of anxiety, depression and kinesiophobia. After the intervention, there was a significant improvement in the perception of quality of life and of all parameters evaluated $(p<0.05)$, with functional gains as well as decreased pain threshold. Conclusion: The interdisciplinary intervention in patients with failed back surgery syndrome provides better functional performance, decreases the intensity of pain, anxiety and depression symptoms, and improves quality of life. The inclusion of this intervention associated with drug therapy may the patient develop an active and independent lifestyle.
\end{abstract}

Keywords: Low back pain; Interdisciplinary research; Reoperation.

\section{RESUMO}

Objetivo: Avaliar os resultados de um programa interdisciplinar aplicado a pacientes com síndrome pós-laminectomia, visando melhora funcional, modulação da dor, redução de sintomas de ansiedade e depressão e aumento da qualidade de vida. Método: Trata-se de um estudo prospectivo não randomizado, com amostra constituída por um grupo de pacientes com síndrome dolorosa pós-laminectomia diagnosticados com dor persistente ou recorrente após cirurgias da coluna lombar (laminectomia e artrodese) encaminhados para interconsultas na Clínica da Dor ( $n=26)$. Os instrumentos utilizados foram: Inventário Breve de Dor, Questionário Roland-Morris e Inventários Beck de ansiedade e depressão. Para avaliar a qualidade de vida, foi utilizado Questionário Genérico Whoqol-bref ${ }^{13}$ e o medo de se movimentar foi avaliado pela Escala Tampa para Cinesiofobia. Resultados: Houve predomínio de mulheres, a média de idade foi 42,3 \pm 5,8 anos, 43\% eram casados e a média de escolaridade foi de $7 \pm 4,5$ anos. O tempo médio de dor relatado foi de $8 \pm 6,8$ meses, além de níveis altos de ansiedade, depressão e cinesiofobia. Após a intervenção houve melhora significativa na percepção da qualidade de vida e de todos os parâmetros avaliados $(p<0,05)$ observando-se ganhos funcionais, assim como a diminuição do limiar de dor. Conclusão: A intervenção interdisciplinar nos pacientes com síndrome pós-laminectomia proporciona melhor desempenho funcional, diminui a intensidade da dor, os sintomas de ansiedade e depressão, melhorando a qualidade de vida. A inclusão desta intervenção associada ao tratamento farmacológico pode desenvolver um estilo de vida ativo e independente.

Descritores: Dor lombar; Pesquisa interdisciplinar; Reoperação.

\section{RESUMEN}

Objetivo: Evaluar los resultados de un programa interdisciplinario subministrado a pacientes con síndrome postlaminectomía que busca la mejora funcional, la modulación del dolor, la reducción de los síntomas de ansiedad y depresión y calidad de vida. Método: Se trata de un estudio prospectivo no aleatorio de una muestra compuesta por un grupo de pacientes con síndrome doloroso postlaminectomía diagnosticados con dolor persistente o recurrente después de la cirugía de la columna lumbar (laminectomía y fusión) referidos a interconsultas en la Clínica del Dolor $(n=26)$. Los instrumentos utilizados fueron: Cuestionario breve del dolor, Cuestionario Roland-Morris e inventarios de ansiedad y depresión de Beck. Para evaluar la calidad de vida se utilizó el cuestionario genérico WHOQOL-BREF ${ }^{13}$ y el miedo de moverse fue evaluado por la Escala de Tampa de Kinesiofobia. Resultados: Hubo un predominio de mujeres, la edad promedio fue de 42,3 \pm 5,8 años, $43 \%$ eran casados y la educación promedio fue de $7 \pm 4,5$ años. Se reportó una duración promedio del dolor de $8 \pm 6,8$ meses, además 
de altos niveles de ansiedad, depresión y kinesiofobia. Después de la intervención se observó una mejoría significativa en la percepción de la calidad de vida y de todos los parámetros $(p<0,05)$, siguiendo las ganancias funcionales, así como la disminución del umbral del dolor. Conclusión: La intervención interdisciplinaria en pacientes con síndrome postlaminectomía mejora la funcionalidad, disminuye la intensidad del dolor, los síntomas de ansiedad y depresión y mejora la calidad de vida. La inclusión de esta intervención asociada con el tratamiento farmacológico puede proporcionar una vida activa e independiente.

Descriptores: Dolor de la región lumbar; Investigación interdisciplinaria; Reoperación.

\section{INTRODUCTION}

Failed back surgery syndrome (FBSS) is characterized by the persistent maintenance of lumbar and / or lower limb pain complaints in patients previously submitted to lumbar vertebral surgery, with possible changes in physical examination and imaging ${ }^{1}$ resulting in a cascade of clinical and surgical events causing loss of function, reduced quality of life and increased costs to society. ${ }^{2}$

The incidence of FBSS varies considerably in different studies, and different factors involved in its pathophysiology are mentioned..$^{1,3}$ Factors such as incorrect or incomplete diagnosis before surgery, inappropriate surgery, failure to consider the patient's psychosocial profile (anxiety, depression, substance abuse, alexithymia) and the presence of inflammation at the surgical site all contribute to this outcome, ranging from $10 \%$ to $40 \%$ in accordance with the number of spine surgeries performed. ${ }^{4}$

The results of failed back surgery syndrome are extremely variable, ranging from complete relief to a life of pain. Reports indicate that when the initial surgery does not obtain good results, the success rate decreases with each additional surgery. ${ }^{5,6}$ Multiple surgeries in elderly patients also have poorer results. ${ }^{7}$

In this context, rehabilitation intervention is extremely important in this group of patients ${ }^{8}$ by the resource of different therapeutic means. $^{8,9}$ The aim of rehabilitation is to maximize the functional abilities of the individual because, with this syndrome a chronic condition, a comprehensive evaluation of an interdisciplinary pain clinical is indicated for a temporal concept, focusing on the future and not the past.

The aim of this study was to evaluate the impact of a group service based on rehabilitation strategies, guidance for patients, and changes in attitudes and beliefs in relation to pain.

\section{MATERIAL AND METHODS}

This is a prospective non-randomized study conducted with patients with failed back surgery syndrome in an outpatient group of the Pain Clinic, Hospital de Base in São José do Rio Preto/SP/ Brazil. This purpose of this study was to gather knowledge on the effect of a group intervention in these individuals, based on specific protocols and systematic research carried out from August to November 2014, after gaining the approval of the Research Ethics Committee under no. 384/2012.

The population consisted of individuals of both sexes, with a sufficient cognitive level to understand the procedures and follow the guidelines, and who agreed to participate by signing an informed consent form.

A total of 26 patients with painful syndrome were included in the study, having been diagnosed with persistent or recurrent pain after lumbar surgery (laminectomy and arthrodesis). Patients with psychiatric illness, lack of clinical follow-up in the Pain Clinic, metabolic (osteoporosis), inflammatory (arthritis, spondylitis) and oncological diseases, were excluded.

From the $2^{\text {nd }}$ to the $11^{\text {th }}$ sessions (once a week, lasting 60 minutes), patients performed flexibility and stretching exercises, with a gradual improvement in performance ${ }^{10}$ guidance on rest positions, ${ }^{11,12}$ aerobic and paravertebral muscle strengthening exercises, ${ }^{8}$ educational and awareness activities relating to the anatomy of the spine and the physiological aspects of the low back pain,,$^{8,13}$ encourage opportunities for participation social ${ }^{16,17}$ guidance on food education, ${ }^{13}$ ergonomic aspects related to activities of daily living, work and leisure ${ }^{8,13,14}$ and group dynamics for the psychosocial approach ${ }^{15}$. All the sessions were conducted by professionals in the areas of physical therapy, occupational therapy, psychology and social service. Each session was conducted by a professional, with the others as collaborators (Table 1). In the 12th session, the patients were reassessed by the same criteria of efficiency, then the results were compared. All patients continued their pharmacological treatment

The evaluation of patients was performed using a semi-structured interview with sociodemographic data: age, sex, marital status, education, employment status and socioeconomic classification (Brazilian Association of Market Research Institutes/ABIPEME), ${ }^{16}$ weight and height. For measuring pain and its impact on some areas of life, we applied the Brief Pain Inventory (BPI), ${ }^{17}$ which is an instrument comprised of 15 items divided into two parts: the first part evaluates the intensity of pain and the second, the interference of the pain in aspects of life (general activities, mood, ability to walk, sleep, work, relationships with others and enjoyment of life). The intensity and interference of pain are scored from 0 (no pain) to 10 (worst possible pain). The degree of disability was assessed by the Roland-Morris Questionnaire (RM) ${ }^{18}$ which consists of 24 questions, selected to cover a range of aspects related to activities of daily living, pain and function. The questions are objective and simple, with a score of " 1 " for each statement the patient agrees with, and "0" for each statement the patient does not agree with. The score is the sum of the values, with a minimum of " 0 " and a maximum of "24. The closer the score is to "24", the more severe the individual's disability with chronic low back pain is. This questionnaire has a cutoff score of "14", in other words, individuals with a score higher than 14 have disabilities. The validity and reproducibility of the Portuguese version, translated and adapted, are well established in the literature. To evaluate the quality of life, we used the generic WHOQOL-bref ${ }^{19}$ Questionnaire, which comprises 26 questions covering a broad area and four specific domains (physical, psychological, social relationships and environment). The quality of life scores of the WHOQOL-bref domains are from zero to 100; the higher the value for each domain, the better the quality of life. Emotional factors such as anxiety and depression were assessed by the Beck

Table 1. Description of group activities

\begin{tabular}{|c|c|}
\hline $\begin{array}{l}1^{\mathrm{a}} \text { e } 12^{\mathrm{a}} \\
\text { sessions }\end{array}$ & Initial and final evaluation \\
\hline $2^{\mathrm{a}}$ session & $\begin{array}{l}\text { Educational and awareness activities as the } \\
\text { anatomy of the spine and the physiological } \\
\text { aspects of the low back pain } \\
\text { Flexibility and stretching exercises }\end{array}$ \\
\hline $3^{\text {a }}$ session & $\begin{array}{c}\text { Awareness of the possibilities for social participation } \\
\text { Ergonomic aspects related to activities } \\
\text { of daily living, work and leisure }\end{array}$ \\
\hline $4^{\mathrm{a}}$ session & Group dynamics for psychosocial approach \\
\hline $5^{\text {a }}$ session & $\begin{array}{l}\text { Aerobic and paravertebral muscles } \\
\text { strengthening exercises }\end{array}$ \\
\hline $6^{\mathrm{a}}$ session & Guidance on food education \\
\hline $7^{\mathrm{a}}$ session & $\begin{array}{l}\text { Educational and awareness activities } \\
\text { Aspects related to activities of daily living }\end{array}$ \\
\hline $8^{\text {a }}$ session & Exercises with gradual increase of performance \\
\hline $9^{a}$ session & Psychosocial approach \\
\hline $10^{a}$ session & Awareness of the possibilities for social participation \\
\hline $11^{\text {a }}$ session & Group dynamics \\
\hline
\end{tabular}


Scale. In this research we used the Beck Anxiety Inventory (BAI) and the Beck Depression Inventory (BDI). The BA ${ }^{20}$ was proposed to measure the common symptoms of anxiety. It consists of 21 symptoms listed, with four alternatives for each one, in ascending order of level of anxiety. The scale classifies anxiety as minimum (0-9 points); mild (10-16 points); moderate (17-29 points); and severe (30-63 points). The BDI ${ }^{21}$ comprises 21 categories of symptoms and activities, containing four alternatives for each one, in ascending order by level of depression. The patient is asked to choose the answer that best fits their symptoms in the last week. The sum of the scores identifies the level of depression. The following result is proposed for the degree of depression: minimum (from 0-11 points); mild (12-19 points); moderate (20-35 points); and severe (36-63 points). Excessive fear of movement and physical activity, which results in feelings of vulnerability to pain or fear of recurrence of the lesion, was observed by the Tampa Scale of Kinesiophobia (TSK), ${ }^{22}$ which consists of 17 statements about pain. the patient must decide whether they agree or disagree with each statement, using a four-point scale. The final score is a minimum of 17 and a maximum of 68 points. The higher the score, the greater the degree of kinesiophobia, indicating that the individual is afraid to move because of the low back pain.

As criteria for improvement and worsening, rates of score changes were calculated, for the questionnaires applied before and after the group intervention.

We performed a descriptive analysis for all the study variables. The analyses were performed by ANOVA to determine differences. To see which variables differed, the non-parametric Wilcoxon and Mann Whitney tests were applied. The significance level used for the tests was 0.05

\section{RESULTS}

Our sample consisted mainly of females (67\%), married (43\%), with a mean age of $42.3 \pm 5.8$ years. In relation to socioeconomic classification, there was a predominance of the category low ( $1 / 2$ to 2 minimum wages). More than half of the sample belonged to this socioeconomic level (55.7\%). In relation to current occupation, $46 \%(n=12)$ of the patients were inactive (disability insurance). The mean pain time of these patients before joining the group was $8 \pm 2.5$ months. No patients were lost to follow-up.

Other data regarding the sociodemographic and clinical profile are shown in Table 2.

Regarding pain and fear of movement, the table below (Table 3) shows a comparison between the pre and post-intervention periods.

The relationship between perceived quality of life in the pre- and post-intervention periods is shown in the figure below (Figure 1).

The levels of anxiety and depression decreased after the interdisciplinary intervention, (Figure 2) showing statistical difference $(p<0.05$, ANOVA test $)$

Table 2. Characterization of sociodemographic and clinical profile of the study group $(n=26)$

\begin{tabular}{c|c|c|c}
\hline Variable & $\mathbf{N}$ & Mean and standard deviation ( \pm ) & $\%$ \\
\hline Education & 26 & $7 \pm 4.5$ years & \\
\hline Weight & $\mathbf{2 6}$ & & \\
\hline $50-60 \mathrm{~kg}$ & & & 38.4 \\
\hline $61-70 \mathrm{~kg}$ & & & 34.6 \\
\hline$>70 \mathrm{~kg}$ & & & 27 \\
\hline Height & $\mathbf{2 6}$ & $\mathbf{1 . 6 2} \pm \mathbf{1 0 . 8} \mathbf{~ m}$ & \\
\hline Pain Duration & 26 & $8 \pm 6.8$ meses & \\
\hline Number of Surgeries & & 2.2 & \\
\hline Employment Status & $\mathbf{2 6}$ & & \\
\hline Formal Working & & & 7.9 \\
\hline Disability Insurance & & & 26.9 \\
\hline Retired & & & 19.2 \\
\hline Informal Working & & &
\end{tabular}

Table 3. Mean values according to the Tampa Scale of Kinesiophobia (TSK) and Brief Pain Inventory (BPI) pre-and-post-group intervention $(n=26)$.

\begin{tabular}{c|c|c|c}
\hline Instruments & $\begin{array}{c}\text { Initial evaluation } \\
\text { average and } \\
\text { SD ( } \pm \text { ) }\end{array}$ & $\begin{array}{c}\text { Average reevaluation } \\
\text { and SD ( } \pm \text { ) }\end{array}$ & P-Value \\
\hline BPI & $9.04 \pm 2.3$ & $6.30 \pm 3.45$ & $0.03^{*}$ \\
\hline Pain Intensity & & & \\
\hline $\begin{array}{c}\text { Pain interference } \\
\text { with general activity }\end{array}$ & & $6.50 \pm 2.04$ & $0.04^{*}$ \\
\hline Mood & $8.35 \pm 3.04$ & $6.60 \pm 3.67$ & 0.06 \\
\hline Ability to walk & $7.32 \pm 2.50$ & $5.20 \pm 2.72$ & $0.03^{*}$ \\
\hline Sleep & $9.35 \pm 1.98$ & $6.12 \pm 4.09$ & $0.05^{*}$ \\
\hline Work & $8.50 \pm 2.35$ & $2.93 \pm 1.99$ & $0.04^{*}$ \\
\hline $\begin{array}{c}\text { Personal } \\
\text { relationship }\end{array}$ & $5.65 \pm 3.25$ & $3.81 \pm 1.86$ & 0.06 \\
\hline Enjoyment of life & $6.50 \pm 3.50$ & $26.4 \pm 5.82$ & $0.03^{*}$ \\
\hline TSK & $49.5 \pm 6.73$ & &
\end{tabular}

Table Caption: BPI - Brief Pain Inventory; TSK - Tampa Scale of Kinesiophobia. ${ }^{*} \mathrm{P} \leq 0.05$ - Wilcoxon non-parametric test

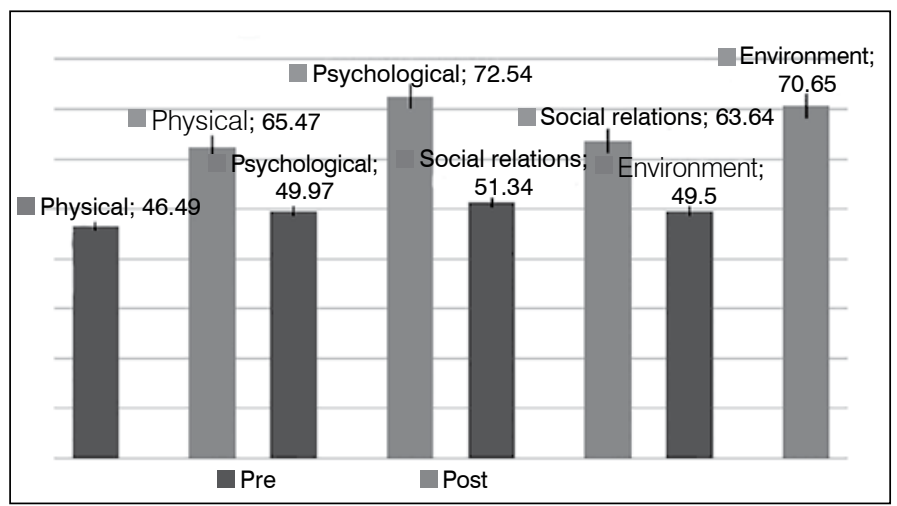

Figure 1. Distribution (\%) of the domains (physical, psychological, social relations, environment) of quality of life, pre- and post-intervention.

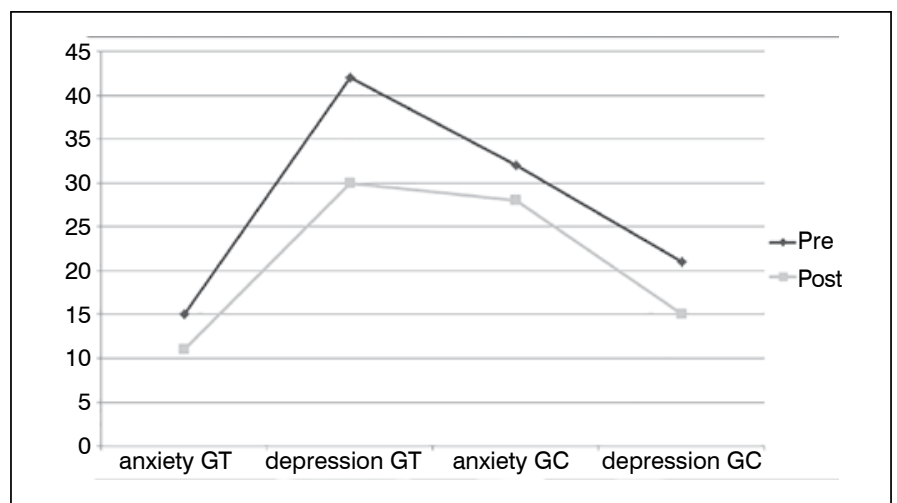

Figure 2. Levels of anxiety and depression assessed by the Beck Scale (BAl-anxiety and BDI-depression) pre and post interdisciplinary intervention $(n=26)$.

The group initially had greater functional disabilities $(17.05 \pm 3.48)$ assessed by the Roland Morris Questionnaire. We observed statistically significant difference in post-intervention functional capacity $(6.78 \pm 2.35, p=0.02)$, and decreasing physical limitations of referred pain in the lumbar spine (Mann Whitney test).

\section{DISCUSSION}

The objective of this study was to evaluate the response of patients with failed back surgery syndrome to participating in an interdisciplinary program, in terms of pain, functional limitations, quality of life and emotional disturbances. 
The instruments used in this study were important to verify the effectiveness of treatment and the patients' responses to it, as well as determining the individual needs, even though the service was performed in a group setting.

The mean age of the study population was 42.3 years, and there was a high incidence of incapacity for work $(68 \%)$ with disability insurance. This corroborating the work by Steenstra et al. ${ }^{23}$ Regarding sex, the majority of the patients were female. In the study by Heyer et al., ${ }^{12}$ these levels were similar, but the work by Teixeira et al found different levels. ${ }^{24}$

In the present study, body weight was above the anthropometric parameters. Several studies have identified increased weight as an important risk factor for increasing pain before or after surgery. ${ }^{20,21}$

In relation to socioeconomic situation, the most prevalent in this study is consistent with the work by Martinez et al. ${ }^{14}$ The results report that educational work should be undertaken in this social group, since it provides organizational behavior changes (structural) able to benefit the health of this population.

Self-perception of improved quality of life and decreased pain intensity after the interdisciplinary program were significant, corroborating the study by Al Kaysi et al. ${ }^{25}$ who propose a care pathway for patients with failed back surgery syndrome with temporal concept, focusing on the future and not the past. This study defines an optimized care pathway, with a multidisciplinary program combining intensive physical rehabilitation with cognitive and behavioral treatment for pain management.

This study also demonstrated that patients after surgery showed an improvement in symptoms of anxiety and depression. The data are similar to those previously reported in the literature for patients with chronic pain. ${ }^{19,24}$ Meinhart and McCaffery ${ }^{26}$ also point out that anxiety is a feeling often associated with acute pain, and is recognized as being responsible for increased pain perception. Anxiety is related to the intensity of pain and the possible meanings that the pain has for the patient. Another factor demonstrated by McGregor and Hughes ${ }^{27}$ is that patients undergoing surgery for lumbar stenosis have unrealistic expectations of the treatment, and this is associated with poorer satisfaction scores in the postoperative period. In this regard, the detailed preoperative evaluation and clarification are extremely important for patients and their families, because the underlying disease and the surgery can affect their activities of daily living.

Regarding fear of movement, this is a risk factor for increased pain, disability and reduced physical function in patients after back surgery. ${ }^{17}$ In this study, performing exercises, stretching, ergonomic counseling and cognitive-behavioral approach led to the groups achieving better muscular and aerobic conditioning, and encouraged the patients to perform regular exercises, improving their functional performance. In the study by Archer et al., ${ }^{13}$ the researchers conducted a multicenter pilot study, using a similar approach in postoperative groups with pain, obtaining satisfactory results. Given this context, we noted that the use of targeted programs to improve the quality of life and functionality has practical implications for the integral management of these patients.

\section{CONCLUSION}

Based on the data of the present study, we conclude that the interdisciplinary intervention in patients with failed back surgery syndrome provided better functional performance, decreased the severity of pain, anxiety and symptoms of depression, and improved their quality of life. The inclusion of this intervention, combined with pharmacological treatment, can systematically develop self-regulation skills needed for the rehabilitation transition to maintain an active and independent lifestyle, adding specific activities to their daily or weekly planning, and the regular follow-up should stimulate longterm maintenance of behavioral change.

All the authors declare that there are no potential conflicts of interest regarding this article.

CONTRIBUTIONS OF THE AUTHORS: Each author made an individual and significant contribution to the development of the manuscript. JENF, AMRC, CEDR and GMAF collected and evaluated the clinical data, MRIM, MHAAF, LCD and RSJ evaluated the data from the statistical analysis, performed the literature review, revised the manuscript, and contributed to the intellectual concept of the study.

\section{REFERENCES}

1. Slawsky A, Hennemann SA. Análise retrospectiva das causas de falha no tratamento cirúrgico das doenças da coluna vertebral. Coluna/Columna. 2008;7(3):235-40

2. Manca A, Eldabe S, Buchser E, Kumar K, Taylor RS. Relationship between health-related quality of life, pain, and functional disability in neuropathic pain patients with failed back surgery syndrome. Value Health. 2010;3(1):95-102.

3. Matias AC, Antunes F. Qualidade de vida na síndrome de cirurgia lombar falhada. Rev Soc Port Med Fls Reab. 2012;21(1):32-6.

4. Chan CW, Peng P. Failed back surgery syndrome. Pain Med. 2011;12(4):577-606.

5. Thomson $S$, Jacques $L$. Demographic characteristics of patients with severe neuropathic pain secondary to failed back surgery syndrome. Pain Pract. 2009;9(3):206-15.

6. Sciubba DM, Gokaslan ZL. Spinal cord stimulation for failed back surgery syndrome-does it work and is it cost-effective? Nat Clin Pract Neurol. 2008;4(9):472-3.

7. Archer KR, Seebach CL, Mathis SL, Riley LH, Wegener ST. Early postoperative fear of movement predicts pain, disability, and physical health six months after spinal surgery for degenerative conditions. J Spine. 2014:13(5):759-67.

8. Miller B, Gatchel RJ, Lou L, Stowell A, Robinson R, Polatin PB. Interdisciplinary treatment of failed back surgery syndrome (FBSS): a comparison of FBSS and non-FBSS patients. Pain Pract. 2005;5(3):190-202.

9. Martins MRI, Polvero LO, Rocha CE, Foss MH, Santos Junior R. Uso de questionários para avaliar a multidimensionalidade e a qualidade de vida do fibromiálgico. Rev Bras Reumatol. 2012;52(1):21-6.

10. Hussain A, Erdek M. Interventional pain management for failed back surgery syndrome. Pain Pract. 2014;14(1):64-78.

11. Nijs J, Meeus M, Cagnie B, Roussel NA, Dolphens M, Van Oosterwijck J, et al. A modern neuroscience approach to chronic spinal pain: combining pain neuroscience education with cognition-targeted motor control training. Phys Ther. 2014;94(5):730-8.

12. Heyer EJ, Sharma R, Winfree CJ, Mocco J, McMahon DJ, McCormick PA, et al. Severe pain confounds neuropsychological test performance. J Clin Exp Neuropsychol. 2008;22(5):633-9.

13. Archer KR, Coronado RA, Haug CM, Vanston SW, Devin CJ, Fonnesbeck CJ, et al. A comparative effectiveness trial of postoperative management for lumbar spine surgery: changing behavior through physical therapy (CBPT) study protocol. BMC Muscul Disord. 2014;15:325.

14. Martinez AP, Martinez JE, Lanza LB. Há correlação entre classe social e a prática de atividade física? Acta Fisiatr. 2011:18(1):27-31.

15. Boonstra AM, Reneman MF, Waaksma BR, Schiphorst Preuper HR, Stewart RE. Predictors of multidisciplinary treatment outcome in patients with chronic musculoskeletal pain. Disabil Rehabil. 2015;37(14):1242-50.

16. Associação Brasileira de Institutos de Pesquisa de Mercado (Abipeme). Classificação socioeconômica - critério Abipeme. Anexo 3. [acesso em 2015 jan 28]. Disponível em: http://www.ufrn.br/sites/fonprace/perfil_anexo3.doc

17. Cleeland C, Ryan K. Pain assessment:global use of the Brief Inventory. Ann Academy Med Singapore.1994;23(2):129-38.

18. Nusbaum L, Natour J, Ferraz MB, Goldenberg J. Translation, adaptation and Validation of the Roland-Morris questionnaire - Brazil Roland Morris. Braz J Med Biol Res. 2001;34(2):203-10.

19. Fleck MP, Louzada S, Xavier M, Chachamovich E, Vieira G, Santos L, et al. Application of the Portuguese version of the abbreviated instrument of quality life WHOQOL-bref. Rev Saude Publica. 2000;30(2):178-83.

20. Cunha JA. Inventário Beck de Ansiedade (BAI). Manual da versão em português das escalas Beck. São Paulo: Casa do Psicólogo; 2001.

21. Cunha JA. Inventário Beck de Depressão (BDI). Manual da versão em português das escalas Beck. São Paulo: Casa do Psicólogo; 2001.

22. Siqueira FB; Teixeira-Salmela LF,Magalhães LC. Análise das propriedades psicométricas da versão brasileira da escala tampa de cinesiofobia. Acta Ortop. Bras. 2007:15(1)19-24.

23. Steenstra IA, Franche RL, Furlan AD, Amick B 3rd, Hogg-Johnson S. The Added Value of Collecting Information on Pain Experience When Predicting Time on Benefits for Injured Workers with Back Pain. J Occup Rehabil. 2016;26(2):117-24

24. Teixeira MJ, Atento LT, Garcia OG, Fonoff ET, Paica WS. Síndrome dolorosa póslaminectomia: estudo descritivo da abordagem terapêutica em 56 pacientes. Rev Assoc Med Bras. 2011;57(3):286-9.

25. Al Kaisy A, Pang D, Desai MJ, Pries $P$, North $R$, Taylor RS. Failed back surgery syndrome: who has failed? Neurochirurgie. 2015:61(1);S6-S14

26. Meinhart NT, McCaffery M. Pain: a nursing approach to assessment and analysis. New York: Appleton-Century; 1983.

27. McGregor AH, Hughes SP. The evaluation of the surgical management of nerve root compression in patients with low back pain: Part 2: patient expectations and satisfaction. Spine (Phila Pa 1976). 2002;27(13):1471-6. 